\title{
THE EFFECT OF AIRLINE DEREGULATION ON AUTOMOBILE FATALITIES
}

by

\section{Lance F. Bylow and Ian Savage \\ Department of Economics \\ Northwestern University}

\author{
Draft Manuscript. \\ Final version published in Accident Analysis and Prevention \\ vol. 23(5), pages 443-452, 1991
}

\begin{abstract}
$\underline{\text { ABSTRACT }}$
This paper attempts to quantify the effects of airline deregulation in the United States on intercity automobile travel and consequently on the number of highway fatalities. A demand model is constructed for auto travel which includes variables representing the price and availability of air service. A reduced form model of the airline market is then estimated. Finding that deregulation has decreased airfares and increased flights, it is estimated that auto travel has been reduced by 2.2\% per year on average. Given assumptions on the characteristics of drivers switching modes and the types of roads they drove on, the number of automobile fatalities averted since 1978 is estimated to be in the range 200-300 per year.
\end{abstract}


In recent years there has been a considerable debate as to whether the deregulation of airline services in the United States has compromised safety. The debate has centered on questions of the performance of airlines brought close to bankruptcy due to competition (Rose, 1990), new entrant jet airlines (Kanafani and Keeler, 1989), and the relative safety of small "commuter" carriers who have replaced jet airlines on lightly travelled routes (Oster and Zorn, 1989).

While there are some areas of concern, particularly with regard to commuter carriers and congestion at major airports, actual accident data suggests that safety has improved since deregulation. In the eleven years prior to deregulation (1968-1978) 387 air accidents occurred causing 1955 fatalities while, from 1979 to 1989, 237 accidents occurred causing 1139 fatalities. When one takes into account the great expansion in demand, the accident rate per one million aircraft departures decreased from 6.5 per year during the former period to 3.5 per year during the latter period. While it is true that accident rates for civil aviation have been declining continually for the past 50 years, Kanafani and Keeler (1990) found no evidence to suggest that deregulation has slowed the rate of improvement in airline safety.

An area of the debate that has been comparatively ignored is the safety implications of a shift from automobile to air travel brought about by the decline in the price of air relative to highway transport since deregulation. Given that fatalities per billion passenger miles have been estimated at 12.8 for auto travel and 0.264 for airline travel, the nation would experience a substantial benefit from any diversion from the automobile (U.S. Department of Commerce, 1989). The purpose of this paper is to estimate the number of annual highway fatalities averted due to regulatory reform of the airline industry.

\section{PREVIOUS LITERATURE}

McKenzie and Warner (1987) tried to determine the effects of airline deregulation on automobile travel. A linear model, using data from 1966-1985, was constructed to estimate the number of ground miles travelled. Five explanatory variables were used: total population, real disposable income per capita, the average highway speed of motor vehicles, an auto transportation price index, and one of two dummy variable structures to account for airline deregulation. Regressions using a simple dummy variable suggested that deregulation decreased total passenger vehicle miles travelled by $3.9 \%$ per year. Use of a Spline dummy variable suggested an even larger reduction, in that total passenger vehicle miles travelled decreased by a cumulative $1.4 \%$ for each post-deregulation year. Consequently, they estimated that 1700 automobile fatalities have been averted each year since 1978.

\section{MODEL}

Our quantification of the effect of airline deregulation on the number of highway automobile fatalities is a four stage process. The first stage is the estimation of a model of highway demand incorporating variables representing the price and quality of air travel. The second stage is to calculate the effect of airline deregulation on these variables. In the third stage 
the estimated changes in air price and quality are used to determine the change in auto demand caused by deregulation. Finally the changes in auto mileage are used to estimate changes in the number of fatalities. Our study uses a national time series analysis of annual data from 1965 to 1988.

\subsection{Demand for Intercity Automobile Travel}

A relatively standard automobile demand equation was employed (for a review of the related gasoline demand literature see Blum et al., 1988). The dependent variable used is an amalgamation of personal passenger vehicle miles for urban Interstate, rural Interstate, and other arterial rural roads. These are the roads on which one would to find the automobile travel that could possibly be abstracted by commuter or jet air travel. ${ }^{1}$

Six explanatory variables were used. The total number of airline departures for commuter and jet aircraft as well as the number of miles of Interstate Highway were included to measure the qualitative aspects of air and auto travel respectively. The number of licensed drivers, the potential consumers of automobile travel, and the average speed of highway automobile travel, were also included. To account for macroeconomic activity, real per capita Gross National Product (GNP) was used. Finally, a cost ratio of real air price to real gasoline price was created to measure the relative price of air travel to automobile travel. ${ }^{2}$ Full details of the data sources for these variables are contained in the appendix.

A common problem encountered when estimating time series automobile (or gasoline) demand models is multicollinearity. We also suffered from this problem. A correlation matrix of the explanatory variables provided some evidence of correlation problems, and our estimated models produced the characteristic high $\mathrm{R}^{2}$. A conventional way of trying to cure this problem is to use first-differencing techniques. However this would have been unsuitable for our purposes as we will be using a shift rather than slope dummy variables to calculate the effect of deregulation on air price and departures. Additionally, while multicollinearity biases standard errors and the $\mathrm{R}^{2}$, it does not affect the estimated coefficients. Given that we are ultimately only interested in using the model for prediction purposes, we were not troubled by using a model with multicollinearity.

However, the biasing of standard errors and the $\mathrm{R}^{2}$ does mean that it is difficult to appraise whether certain variables should be included in the model and also the form of the equation. We therefore tested a variety of forms using a first-differenced version of the model.

\footnotetext{
${ }^{1}$ We thereby exclude traffic on urban, and rural town, streets. Traffic on these streets is not in competition with air service, and may be affected by factors such as the price and quality of mass transit, and demographic and workplace changes. Any persons changing intercity mode from auto to air would still need to use the local road network to access the airport. The exclusion of urban traffic does, however, preclude estimation of additional fatalities occasioned by the increased travel to and from airports by those persons whose trips have been generated by airline deregulation.

${ }^{2}$ Two measures of the relative cost of air to automobile travel were tried. In the selected relative cost ratio, the real price of gasoline was chosen to represent the cost of automobile travel since it is the figure that many consumers will use when making a choice between an auto and an air trip. An alternative measurement, total automobile operating costs per mile, which includes factors such as depreciation and insurance costs, was obtained, but was found to perform less well in our estimated equations.
} 
Our preferred log-linear model is shown in the non-first-differenced form in table 1, and in a first-differenced form in table 2. In the latter case the $\mathrm{R}^{2}$ fell to 0.75 . Both versions had DurbinWatson statistics within the range that suggests that autocorrelation was not a problem.

The variables had similar signs and significance in both versions of the model, and generally had the expected signs. An increase in the number of airline departures reduced auto demand, and the expansion of the Interstate Highway system increased it, although in both cases the effect was statistically insignificant. The number of licensed drivers and the average highway speed had significant positive effects. Importantly, the relative cost of air travel to automobile travel is positive and significant, suggesting that we are indeed dealing with substitute goods. The GNP per capita variable changed its sign when first-differencing was employed, although it was highly statistically insignificant in both model versions. Alternative measures of economic activity were tried but these performed even more poorly.

\subsection{Effects of Deregulation on the Airline Industry}

The second stage of the analysis is concerned with predicting how the real price of air travel and the number of airline departures have changed due to airline deregulation. A structural model of the airline industry was specified based on an assumption of profit maximization.

$$
\max \pi=P \text { x } q(P, D, X, Z)-c[q(P, D, X, Z), D, W, Y, Z]
$$

where: $\quad \pi=$ profits

$\mathrm{P} \quad=\quad$ airline fares (i.e., price)

$\mathrm{q}(\cdot)=$ a demand function

$c(\cdot)=$ a total cost function

$\mathrm{D}=$ number of departures (a measure of quality)

$\mathrm{W}=$ factor prices (assumed exogenous)

$\mathrm{X}=$ other (exogenous) demand factors

$\mathrm{Y}=$ other (exogenous) cost factors

$\mathrm{Z}=$ deregulation effect

This gives first order conditions:

$$
\begin{gathered}
\partial \pi / \partial \mathrm{P}=\mathrm{q}(\mathrm{P}, \mathrm{D}, \mathrm{X}, \mathrm{Z})+(\mathrm{P} \times \partial \mathrm{q}(\cdot) / \partial \mathrm{P})-\partial \mathrm{c}(\cdot) / \partial \mathrm{P}=0 \\
\partial \pi / \partial \mathrm{D}=(\mathrm{P} \times \partial \mathrm{q}(\cdot) / \partial \mathrm{D})-\partial \mathrm{c}(\cdot) / \partial \mathrm{D}=0
\end{gathered}
$$

Assuming a linear, separable, demand function and a Cobb-Douglas cost function these conditions give two structural equations:

$$
\begin{gathered}
P=f_{1}(D, W, X, Y, Z) \\
D=f_{2}(P, W, Y, Z)
\end{gathered}
$$


Given full specification of these equations, and having ensured identification, estimation could be made using two-stage least squares. However as we are simply interested in predictions of P and $\mathrm{D}$ these can be made using reduced form equations (Judge et al., 1985, page 573).

$$
\begin{aligned}
& P=g_{1}(W, X, Y, Z) \\
& P=g_{2}(W, X, Y, Z)
\end{aligned}
$$

In the reduced form regressions, seven exogenous factors were used. Two factor prices were included, namely real air compensation (i.e., wages) and the real price of jet fuel. ${ }^{3}$ Real air compensation and real jet fuel costs were selected since they account for a large proportion of the airlines' operating budgets. In 1988, jet fuel costs accounted for $15 \%$ of the operating costs while compensation to airline employees accounted for $38 \%$ of the operating costs. Other cost factors were also included. The inclusion of average available seats per aircraft mile allowed for the technological advances over this twenty-four year period which has permitted some reaping of economies of aircraft size. ${ }^{4}$ The average passenger trip distance was chosen due to its influence on operating costs and on the level of airfares. A linear time trend variable was included to pick up the effects of any exogenous cost factors not accounted for in the other variables as well as the effects of any excluded exogenous demand forces. Examples of such exogenous demand factors are described in Gómez-Ibáñez and Pickrell (1987) who conclude that demographic changes such as higher household incomes and smaller family size have increased the mode share of air service.

Besides the exogenous variables mentioned, two dummy variables were included in these two reduced form equations. The first dummy was designed to quantify the effects of airline deregulation. It was assigned the value of one for all years following deregulation including 1978. This dummy variable was constrained to a shift dummy rather than a slope dummy, which admittedly is a strong assumption, because of the small number of data points we were working with.

A second dummy variable proved necessary because without it the regression coefficients were too heavily influenced by the early years included in this study. When plotting real airfares versus time, one could see that in the first four years, 1965 to 1968, airfares dropped quickly only to decrease at a slower rate until deregulation accelerated the decline again. A similar pattern, in reverse, was noted with regard to departures. This period was atypical due to the drastic technological and economic changes experienced by the airline industry with the introduction of the jet aircraft. It could be argued that one should exclude these early years. However as we have a relatively short time series, the inclusion of these years along with a dummy variable was considered worthwhile in order to gain three degrees of freedom.

\footnotetext{
${ }^{3}$ We acknowledge that, particularly in the market for pilots, airline firms and unions may have considerable monopsonistic and monopolistic power over wages, and hence the factor price may not be fully exogenous.

${ }^{4}$ The average aircraft size increased from 96 seats in 1965 to 117 in 1970 to 169 in 1988 . Some of this increase will be accounted for by the introduction of widebody jets on international services.
} 
The results of the two reduced form regressions are given in Tables $3 \mathrm{~A}$ and $3 \mathrm{~B}$. The estimated coefficients of the deregulation dummy imply that real airfares have fallen $8.6 \%$ due to deregulation and that departures have increased by 6.7\%. Albeit that in the latter case the effect was statistically insignificant. The results are graphically represented in Figures 1 and 2. Our results are not that dissimilar to those of Morrison and Winston (1986). They concluded, using 1983 data, that fares fell by about $10 \%$ and that frequencies on city pairs of less than 500 miles increased by $11 \%$.

As with the automobile demand model, our estimated log-linear reduced form regressions also had multicollinearity problems, as witnessed by the high $\mathrm{R}^{2}$ in both regressions. Again, first differencing was used to attempt to eliminate these problems. The correlation problem was decreased but not substantially. Upon closer examination, some of the correlation appeared unavoidable. For example, time and real compensation of airline employees were highly correlated as were the real price of jet fuel and time. As with the automobile demand model, we were not unduly worried as we were only interested in predictions of fares and departures. Durbin-Watson tests indicated that autocorrelation was not a problem.

\subsection{Estimation of Changes in Intercity Automobile Travel}

The predicted changes in airline fares and departures were then run in the intercity automobile demand function to determine the levels of intercity automobile vehicle miles which would have been travelled had deregulation not been enacted. The result is graphically depicted in Figure 3. This study suggests that over the eleven year period from 1978 through 1988104 billion intercity automobile miles were not travelled due to the substitution effect of people flying instead of driving.

\subsection{Effect on Automobile Fatalities}

The final step is to estimate how the change in intercity automobile travel attributable to airline deregulation affected the number of highway fatalities. To do this, the relationship between the number of highway fatalities and the number of vehicle miles travelled must be discerned. We accept the finding of McKenzie and Warner (1987) that automobile deaths are proportionally related to the number of vehicle miles travelled. Therefore, the annual highway fatality rate was used to determine the number of automobile deaths averted.

One possible fatality rate appropriate to the type of automobile usage we are interested in is that defined as occurring on federally funded roads. In practice this rate was almost identical to the overall highway death rate. The overall highway fatality rate has declined since 1978. In 1978 the fatality rate per 100 million vehicle miles was 3.39 while in 1988 it was equal to 2.46. This decline, of course, is not attributable to changes caused by airline deregulation, but rather are explained by seat belt laws, an increased awareness of the harms of drinking and driving, and improved safety features of automobiles. ${ }^{5}$

\footnotetext{
${ }^{5}$ One might argue that fewer automobiles on the road due to airline deregulation also caused a reduced probability of collision, but this effect is probably trivial.
} 
However, it may be more appropriate to use the rural fatality rate. Urban streets account for a large proportion of vehicle travel yet a much smaller proportion of fatalities, due to low vehicle speeds. Fatality rates on undivided rural arterial roads are relatively high. The rural rate is about 50\% higher than the national average. In 1978 it was 4.93 per 100 million vehicle miles, declining to 3.91 in 1988.

The annual change in the number of intercity vehicle miles due to deregulation since 1978 was multiplied by the two measures of the fatality rate for each respective year in order to calculate the annual number of fatalities that would have been expected had deregulation not been enacted. The results are listed in Table 4. This suggests that on average 275 additional fatalities per year would have occurred had airline deregulation not been enacted using the overall highway fatality rate. The equivalent figure using the rural accident rate is 400 per year.

There is one further consideration. Airline passengers, once boarded, cannot influence the probability of an accident. The same cannot be said for people behind the wheel of their cars. One should ask whether the types of people who have shifted mode from auto to air are "typical drivers". Evans et al. (1990) analyze the sex and age of airline passengers and suggest that such people, when driving, have a $24.1 \%$ lower fatality rate than the average driver. ${ }^{6}$ One could question whether this is an appropriate figure if the expansion of demand for airline travel has come from non-traditional age ranges and social classes. Evans et al. suggest that the auto accident rate of typical airline passengers may be even lower if they were people more predisposed to wear a seatbelt, refrain from drinking, and drive a large auto. We have no evidence to bring to bear on these propositions. Making the reasonable assumption that the typical person changing modes is $24.1 \%$ safer on the highway than average reduces the average fatalities averted to 205 or 307 depending on whether one uses the total highway fatality rate or just that for rural roads.

\section{CONCLUDING REMARKS}

Using a reduced form model of the airline industry we estimate that deregulation has lowered real airline fares by $8.6 \%$ and increased the number of flights by $6.7 \%$. Using these values in a demand equation for intercity automobile trips suggests that a mode shift has occurred that has reduced annual automobile mileage by $2.2 \%$. Having made allowance for the fact that the typical airline passenger is far safer than the "average driver", we conclude that over the eleven year period since 1978 between 2,300 and 3,300 automobile fatalities have been averted due to the effects of airline deregulation on intercity travel patterns.

The number of auto fatalities averted is two to three times higher than the total number of fatalities occurring in commercial aviation over the same period. Thus the policy debate on the impact of airline economic regulatory reform on safety should be focused on the mode shifting implications rather than concentrating on effects internal to the airline industry such as financial distress, new entry, and the substitution of turbo-prop aircraft for jets. Morrison and Winston

\footnotetext{
${ }^{6}$ Airline passengers are predominantly in the 30-50 age group. Among auto drivers the age group which has the highest fatality rates is young people under 25.
} 
(1986) calculated annual benefits from deregulation to be about $\$ 18$ billion at current prices. Valuing each of the 200-300 fatalities a year at \$1.25 million (Jones-Lee et al., 1985) would produce an additional benefit of about one-third of a billion dollars per annum.

In addition, the number of automobile fatalities averted should be non-trivial consideration in current debates on public policy towards the airlines; such as those dealing with increased concentration, the calls for re-regulation, and the solution to capacity constraints at many airports.

\section{APPENDIX - DATA SOURCES}

\section{Intercity Automobile Demand Equation}

The data for Intercity Passenger Vehicle Miles Travelled, the dependent variable, was taken from the table "Annual Vehicle Miles of Travel and Related Data, by Highway Category and Vehicle Type" found in the Federal Highway Administration's Highway Statistics. The variable is an amalgamation of personal passenger vehicle miles travelled for urban Interstate, rural Interstate, and other rural arterial roads.

Airline Departures data comes from responses to Form 41 submitted to the Federal Aviation Administration and earlier to the Civil Aeronautics Board. The total number of scheduled departures for jet and commuter carriers (i.e., parts 14 CFR 121 and 135) was used.

Miles of Road data is obtained from Federal Highway Administration's Highway Statistics table entitled "Federal-Aid System Mileage." The total of rural plus urban Interstate Highway was used. Total Number of Licensed Drivers data is from the Federal Highway Administration's Highway Statistics table entitled "Licensed Drivers, By Sex."

The Relative Cost of Air to Automobile Travel was calculated from three sources. The nominal cost of air travel was defined as the passenger yields of domestic coach class, in cents per passenger mile, as found in Air Transport: The Annual Report of the U.S. Scheduled Airline Industry. These figures then were divided by the Consumer Price Index (CPI) found in the Monthly Labor Review to calculate the real cost of air travel. The Consumer Price Index used was for all items for all urban consumers, with the base year of 1967. The real price of gasoline, in cents per gallon, was calculated by dividing the nominal price of gasoline found in Annual Energy Review of the Energy Information Administration by the CPI. Through 1975, the nominal gasoline price data was equal to the leaded regular gasoline price. In 1976 the nominal gas price was calculated as follows: (.9*leaded gas price $+.1 *$ unleaded gas price), with the weights changing each year until in 1985 , the gas price equaled $\left(0^{*}\right.$ unleaded gas price + $1.0 *$ unleaded gas price). After 1985, the unleaded gas price was used.

Average Highway Speed data was taken from a table in Highway Statistics entitled "Speed Data in Miles Per Hour." 
Real Per Capita GNP was calculated using GNP data from the U.S. Bureau of Labor Statistics Survey of Current Business. Real GNP was calculated by dividing the nominal GNP by the CPI. Real GNP then was divided by U.S. population data found in The Statistical Abstract of the United States "Table No. 2 Population: 1900 to 1988."

\section{Reduced Form Equations of the Airline Industry}

Real Air Compensation was calculated using the following data. The total air compensation per full time employee figures were obtained from the table "Average Annual Earnings and Total Compensation Per Full Time Employee" in Transportation Facts and Trends, which later was continued as Transportation in America. This data was divided by the CPI to calculate the real air compensation.

Real Jet Fuel Cost was determined by dividing the nominal cost of jet fuel by the CPI. The nominal cost data, in cents per gallon, was found in Aircraft Operating Cost and Performance Report for a Passenger Cabin Configuration Turbo Fan 4-Engine for 1965 to 1984. For 1985 to 1988, the data was taken from Transportation in America. The data for Average Passenger Trip Distance in miles was found in Air Transport. Average Available Seats Per Aircraft Mile data was found in Aerospace Facts and Figures.

\section{3. $\quad$ Automobile Fatality Calculations}

The Automobile Death Rate data came from Accident Facts. The rates used were the overall highway fatality rate per 100 million vehicle miles and the rural fatality rate per 100 million vehicle miles. Fatality rates can also be obtained from the Federal Highway Administration's reports entitled "Fatal Injury Accident Rates on Federal-Aid and Other Highway Systems."

\section{REFERENCES}

Aerospace Industries Association of America, (annual). Aerospace Facts and Figures. Washington, D.C.

Air Transport Association of America, (annual). Air Transport: The Annual Report of the U.S. Scheduled Airline Industry. New York.

Blum, U.C.H., G. Foos and M.J.I. Gaudry, (1988). "Aggregate Time Series Gasoline Demand Models: Review of the Literature and New Evidence for West Germany." Transportation Research A 22(2): 75-88.

ENO Foundation for Transportation, (annual). Transportation in America. Washington, D.C. 
Evans, L., M.C. Frick and R.C. Schwing, (1990). "Is It Safer to Fly or Drive?" Risk Analysis 10(2): 239-246.

Gómez-Ibáñez, J.A. and D.H. Pickrell, (1987). "Towards an Equilibrium in Intercity Travel Choices." In Meyer, J.R. and C.V. Oster Jr. Deregulation and the Future of Intercity Passenger Travel. Cambridge, Mass: MIT Press.

Jones-Lee, M.W., M. Hammerton and P.R. Philips, (1985). "The Value of Safety: Results of a National Sample Survey." Economic Journal 95(1): 49-72.

Judge, G.G., W.E. Griffiths, R.C. Hill, H. Lütkepohl and T-C. Lee, (1985). The Theory and Practice of Econometrics (second edition). New York: Wiley.

Kanafani, A. and T.E. Keeler, (1989). "New Entrants and Safety." In Moses, L.N. and I. Savage Transportation Safety in an Age of Deregulation. New York: Oxford University Press.

Kanafani, A. and T.E. Keeler, (1990). "Air Deregulation and Safety: Some Econometric Evidence from Time Series." Logistics and Transportation Review 26(3): 203-209.

National Safety Council, (annual). Accident Facts. Chicago.

McKenzie, R.B. and J.T. Warner, (1987). "The Impact of Airline Deregulation on Highway Safety." (Working Paper OP67.) Center for the Study of American Business, Washington University.

Morrison, S. and C. Winston, (1986). The Economic Effects of Airline Deregulation. Washington, D.C.: Brookings Institution.

Oster, C.V., Jr. and C.K. Zorn, (1989). "Is it Still Safe to Fly?" In Moses, L.N. and I. Savage Transportation Safety in an Age of Deregulation. New York: Oxford University Press.

Rose, N.L., (1990). "Profitability and Product Quality: Economic Determinants of Airline Safety Performance." Journal of Political Economy 98(5): 944-964.

Transportation Association of America, (annual to 1976). Transportation Facts and Trends. Washington, D.C.

United States Civil Aeronautics Board, (annual to 1984). Aircraft Operating Cost and Performance Report. Washington, D.C.: Government Printing Office.

United States Department of Commerce, Bureau of Census, (1989). Statistical Abstract of the United States. Washington, D.C.: Government Printing Office.

United States Department of Labor, Bureau of Labor Statistics, (monthly). Monthly Labor

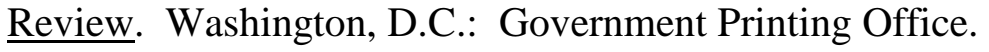


United States Department of Labor, Bureau of Labor Statistics, (annual). Survey of Current Business. Washington, D.C.: Government Printing Office.

United States Department of Transportation. Federal Highway Administration (annual). Highway Statistics. Washington, D.C.: Government Printing Office.

United States Energy Information Administration, (1988). "Motor Gasoline and Residential Heating Oil Retail Prices, 1949-1988." Annual Energy Review 1988. Washington, D.C.: Government Printing Office. 
TABLE 1: $\quad$ Regression Results on Intercity Vehicle Miles Travelled

\begin{tabular}{|l|c|c|}
\hline Independent Variables & Coefficient & T-statistics \\
\hline Constant & -7.741 & $1.760 *$ \\
\hline $\ln$ (Departures) & -0.092 & 0.963 \\
\hline $\ln$ (Road Mileage) & 0.451 & 0.958 \\
\hline $\ln$ (Drivers) & 1.480 & $8.593 * * *$ \\
\hline $\ln$ (Relative Cost) & 0.176 & $2.988 * * *$ \\
\hline $\ln ($ Speed) & 0.785 & $2.977^{* * *}$ \\
\hline $\ln$ (Real GNP per Capita) & 0.034 & 0.155 \\
\hline $\mathrm{R}^{2}$ & 0.992 & \\
\hline Adjusted R & 0.989 & \\
\hline Durbin-Watson & 0.724 & \\
\hline $\mathrm{N}$ & 24 & \\
\hline
\end{tabular}

Significant at the .01 level

** Significant at the .05 level

* Significant at the .10 level 
TABLE 2: $\quad$ First-Differenced Regression Results on Intercity Vehicle Miles Travelled

\begin{tabular}{|l|c|c|}
\hline Independent Variables & Coefficient & T-statistics \\
\hline Constant & 0.016 & 1.563 \\
\hline $\ln$ (Departures) & -0.071 & 0.767 \\
\hline $\ln$ (Road Mileage) & 0.245 & 0.953 \\
\hline $\ln$ (Drivers) & 0.838 & $2.014^{*}$ \\
\hline $\ln$ (Relative Cost) & 0.160 & $3.427^{* * *}$ \\
\hline $\ln$ (Speed) & 0.647 & $3.224^{* * *}$ \\
\hline $\ln$ (Real GNP per Capita) & -0.029 & 0.174 \\
\hline $\mathrm{R}^{2}$ & 0.746 & \\
\hline Adjusted R & 0.651 & \\
\hline Durbin-Watson & 1.429 & \\
\hline $\mathrm{N}$ & 23 & \\
\hline
\end{tabular}

Significant at the .01 level

** Significant at the .05 level

* Significant at the .10 level 
TABLE 3A: Reduced Form Regression Results on Real Airfare

\begin{tabular}{|l|c|c|}
\hline Independent Variables & Coefficient & T-statistics \\
\hline Constant & -5.312 & 1.515 \\
\hline $\ln$ (Real Air Compensation) & -0.272 & 0.989 \\
\hline $\ln$ (Real Jet Fuel) & 0.179 & $3.787^{* * *}$ \\
\hline $\ln$ (Av. Trip Distance) & 1.614 & $2.992^{* * *}$ \\
\hline $\ln$ (Av. Seats per Mile) & -0.311 & 0.545 \\
\hline Time & -0.033 & $3.167^{* * *}$ \\
\hline Dummy variable 1965-68 & 0.055 & 0.994 \\
\hline Dummy variable 1978-88 & -0.086 & $1.947^{*}$ \\
\hline $\mathrm{R}^{2}$ & 0.960 & \\
\hline Adjusted $\mathrm{R}^{2}$ & 0.943 & \\
\hline Durbin-Watson & 1.778 & \\
\hline $\mathrm{N}$ & 24 & \\
\hline
\end{tabular}

Significant at the .01 level

** Significant at the .05 level

* Significant at the .10 level 
TABLE 3B: Reduced Form Regression Results on Airline Departures

\begin{tabular}{|l|c|c|}
\hline Independent Variables & Coefficient & T-statistics \\
\hline Constant & 12.513 & $2.538 * *$ \\
\hline $\ln$ (Real Air Compensation) & -0.269 & 03695 \\
\hline $\ln$ (Real Jet Fuel) & -0.169 & $2.545^{* *}$ \\
\hline $\ln$ (Av. Trip Distance) & -0.498 & 0.656 \\
\hline $\ln$ (Av. Seats per Mile) & -0.453 & 0.566 \\
\hline Time & 0.030 & $2.063 *$ \\
\hline Dummy variable 1965-68 & 00.071 & 0.919 \\
\hline Dummy variable 1978-88 & 0.067 & 1.069 \\
\hline $\mathrm{R}^{2}$ & 0.964 & \\
\hline Adjusted R & \\
\hline Durbin-Watson & 0.948 & \\
\hline $\mathrm{N}$ & 0.889 & \\
\hline
\end{tabular}

Significant at the .01 level

** Significant at the .05 level

* Significant at the .10 level 
TABLE 4: Automobile Deaths Averted due to Airline Deregulation

\begin{tabular}{|l|c|c|c|c|c|}
\hline Year & $\begin{array}{c}\text { Less Auto } \\
\text { Miles } \\
(\text { millions })\end{array}$ & $\begin{array}{c}\text { Auto Death } \\
\text { Rate } \\
(\mathrm{x} \mathrm{10})\end{array}$ & $\begin{array}{c}\text { Auto Deaths } \\
\text { Averted }\end{array}$ & $\begin{array}{c}\text { Rural Auto } \\
\text { Death Rate } \\
(\mathrm{x} \mathrm{10})\end{array}$ & $\begin{array}{c}\text { Auto Deaths } \\
\text { Averted }\end{array}$ \\
\hline 1978 & 8,682 & 3.39 & 294 & 4.93 & 428 \\
\hline 1979 & 8,604 & 3.50 & 301 & 4.82 & 415 \\
\hline 1980 & 8,336 & 3.50 & 292 & 5.00 & 417 \\
\hline 1981 & 8,558 & 3.30 & 282 & 4.63 & 396 \\
\hline 1982 & 9,024 & 2.88 & 260 & 4.11 & 371 \\
\hline 1983 & 9,485 & 2.68 & 254 & 3.91 & 371 \\
\hline 1984 & 9,678 & 2.69 & 260 & 3.98 & 385 \\
\hline 1985 & 9,772 & 2.57 & 251 & 3.94 & 385 \\
\hline 1986 & 10,276 & 2.57 & 264 & 3.99 & 410 \\
\hline 1987 & 10,686 & 2.55 & 272 & 3.99 & 426 \\
\hline 1988 & 10,960 & 2.46 & 270 & 3.91 & 429 \\
\hline TOTAL & 104,062 & & 3,001 & & 4,433 \\
\hline
\end{tabular}




\section{FIGURE 1: Predicted Real Airfares}

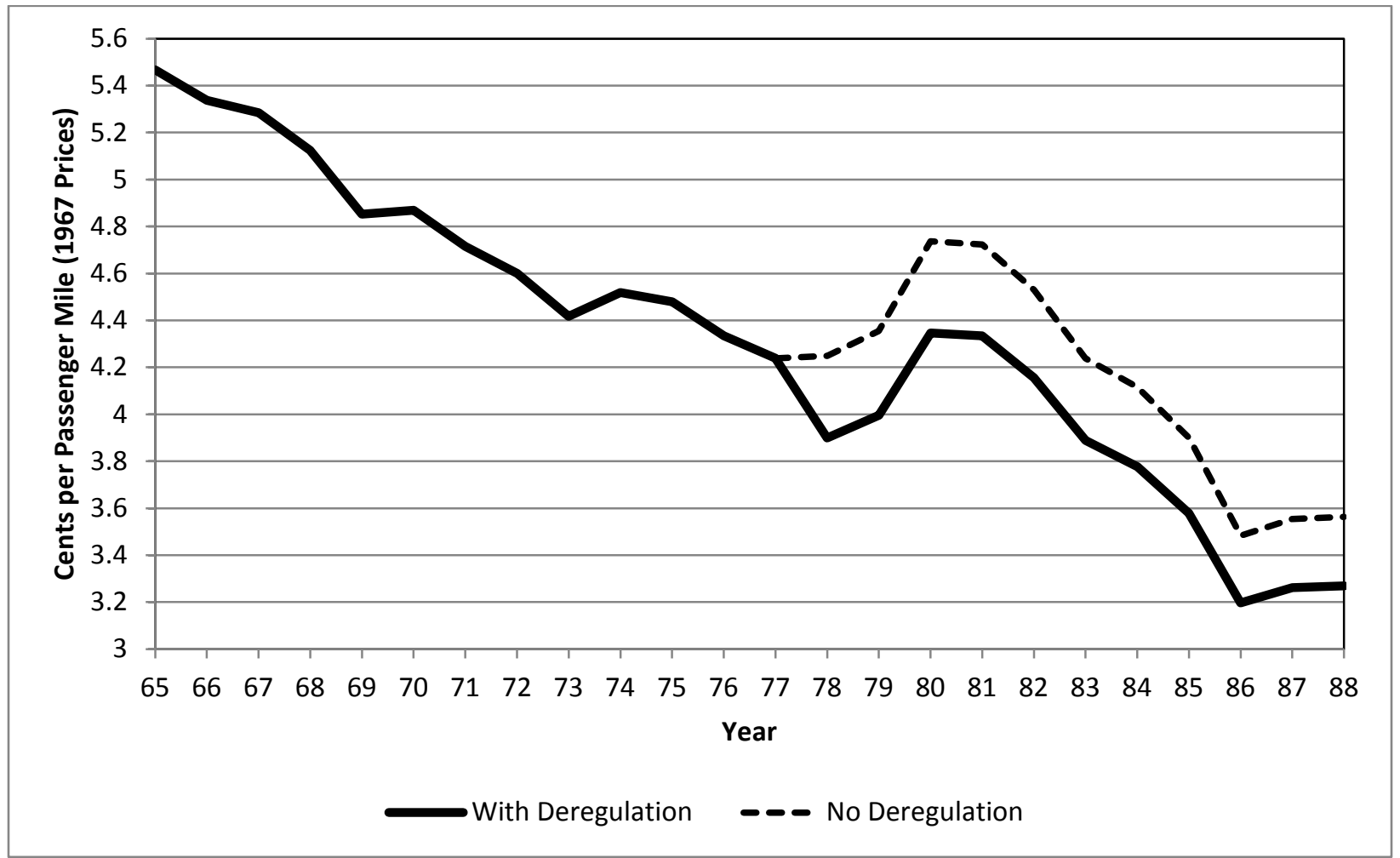


FIGURE 2: Predicted Annual Airline Departures

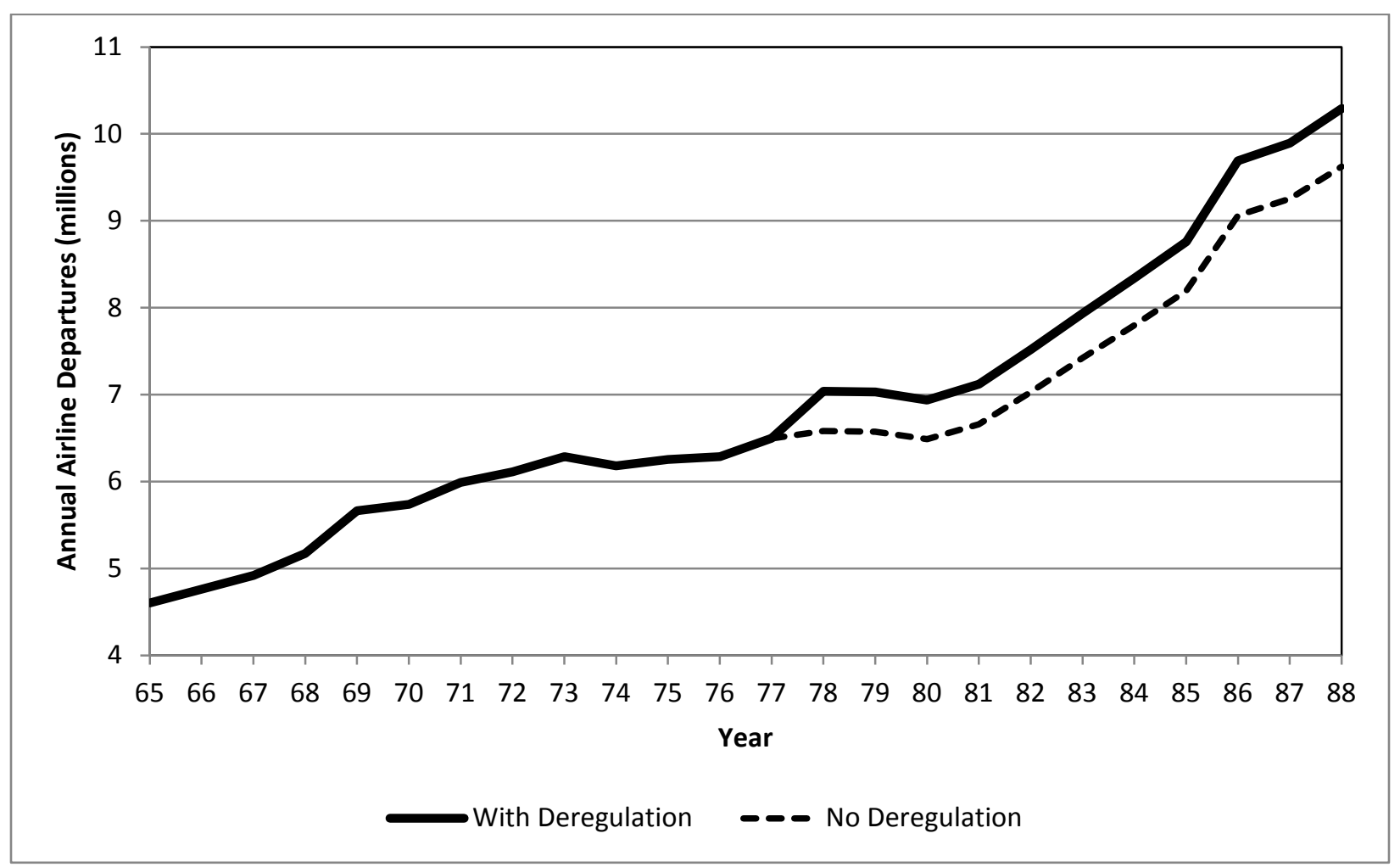


FIGURE 3: Predicted Annual Intercity Automobile Mileage

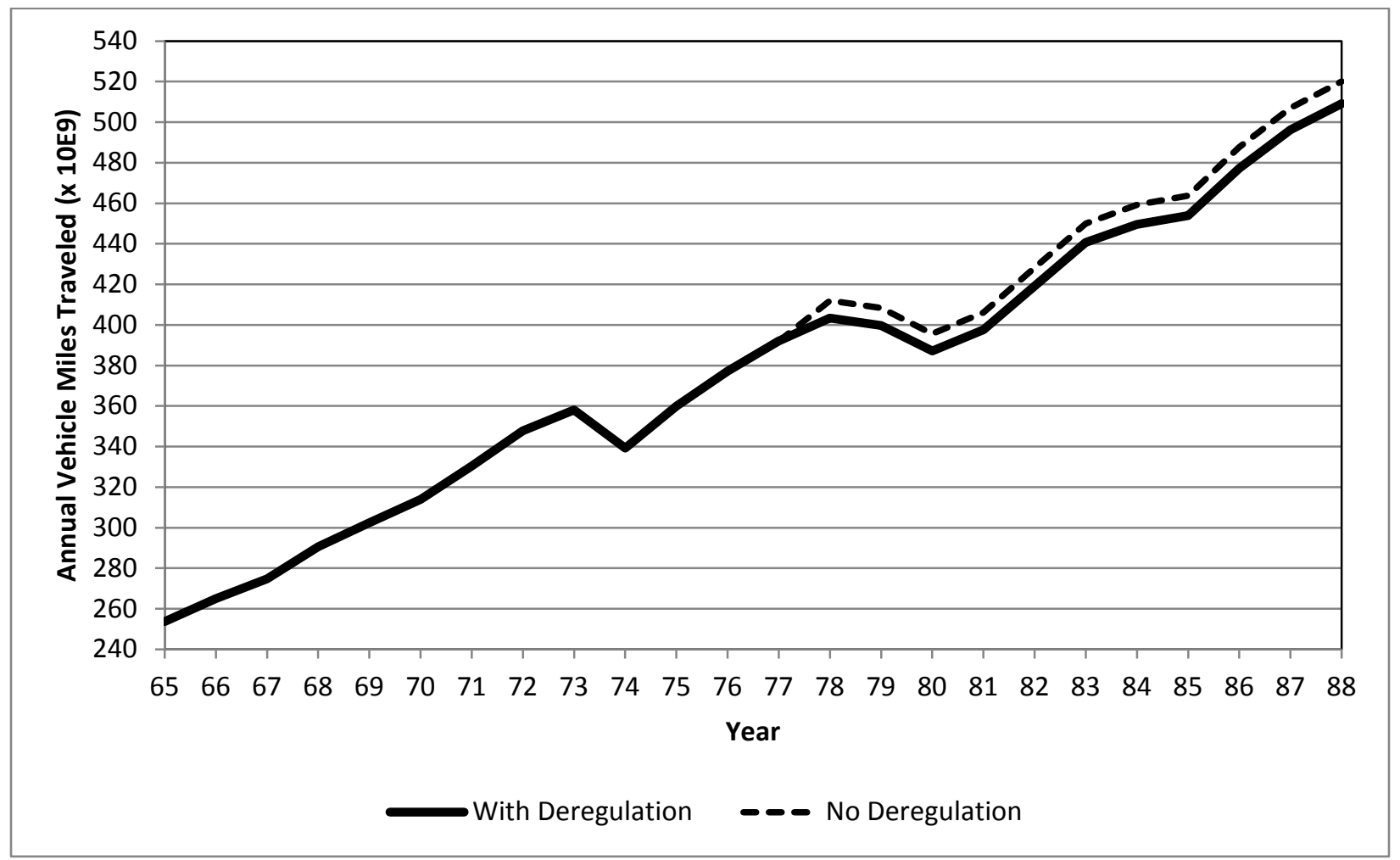

